\title{
Inculturation in the Catholic Church in Indonesia
}

\author{
B. Agus Rukiyanto \\ Sanata Dharma University, Yogyakarta, Indonesia \\ ruky@usd.ac.id
}

"Be one hundred per cent Catholic and one hundred per cent Indonesian."

(Mgrs. Albertus Soegijapranata, S.J.) ${ }^{1}$

\begin{abstract}
Indonesia consists of different ethnicities, cultures, religions, and beliefs. This diversity is a gift, but also a challenge for the Indonesian nation. Differences that exist often cause problems and conflicts between tribes and between religions and beliefs. In the midst of this pluralistic situation, the Church in Indonesia needs to develop inculturation in order to be open and to be able to make dialogue with every culture that exists in Indonesia, with different religions and beliefs as well as with the concrete situation occurring in Indonesia. This paper uses an analytical descriptive method to describe and analyze the concrete situation of the Church in its efforts to respond to socio-religious and political problems and challenges in Indonesia. It appears that the Church in Indonesia is very open and fully respond to every problem and challenge that exist in the midst of Indonesian people and society. This paper is expected to be an inspiration for the local Churches in developing its role to contribute to the development of the nation and the State of Indonesia, as well as to be an inspiration to other Churches in other parts of the world wherever experiencing situations more or less similar to the pluralistic situation in Indonesia.
\end{abstract}

\section{Keywords:}

inculturation, Indonesianisasi, the Indonesian Church, the Indonesian Bishops' Conference, Pancasila, Bhinneka Tunggal Ika

1 Quoted from "Interview with Mgr. Soegijapranata," Katholiek Archief, XIII (July 25, 1958), 716, in Huub J. W. M. Boelaars, Indonesianisasi: Dari Gereja Katolik di Indonesia Menjadi Gereja Katolik Indonesia (Yogyakarta: Penerbit Kanisius, 2005), 112. 


\section{INTRODUCTION}

In this paper I will present the experience of the Catholic Church in Indonesia in developing inculturation as an attempt to become the local Church of Indonesia. Before doing so, I will give a brief introduction of Indonesia and the Catholic Church in Indonesia. Then, I will explain the meaning of inculturation, followed by exploring inculturation as identified by documents of the Indonesian Bishops' Conference (IBC) and by an Indonesian theologian. At the end, I will conclude with reflection on the journey of the Catholic Church in Indonesia.

\section{The Situation In Indonesia ${ }^{2}$}

Indonesia, known before World War II as the Netherlands East Indies, is the world's largest archipelagic country consisting of 17,508 islands (6,000 of them inhabited), with a land area of 2,027,087 square kilometers extending from West to East along 5,110 kilometers (it consists of three separate times zones), and from North to South 1,888 kilometers. Most of these islands lie in a volcanic belt and near the intersection of shifting tectonic plates, which can generate earthquakes and volcanic eruption. ${ }^{3}$ Temperature generally ranges from 20 to 30 degrees Celsius, with high humidity and a lot of rains (rainy season) in October through April.

With its population of more than 262 million (2017 estimation), Indonesia is the world's fourth most populous nation after China, India and the United States. ${ }^{4}$ More than $60 \%$ of the population is concentra-

2 For general information, the official websites of the Indonesian government (http:// www.indonesia.go.id and http://www.lin.go.id/default.asp, accessed January 10, 2018) are primarily used, besides other informational websites, like Indonesia Archeology on the net (http: / / www.arkeologi.net, accessed January 10, 2018), and Infoplease ("Indonesia," in http:/ / www.infoplease.com/ipa/A0107634.html, accessed January 10, 2018).

3 A powerful undersea quake on December 26, 2004 sent massive tsunami crashing into coastal areas of Sumatra and across South and East Asia, killing more than 220,000 people. On May 27, 2006, an earthquake in Yogyakarta, Central Java, killed more than 6,000 people. See "Country Profile: Indonesia," in http://news.bbc.co.uk/2/hi/ asia-pacific/country_profiles/1260544.stm, accessed on January 17, 2018. Also "Java Death Toll Tops 500," in http://edition.cnn.com/2006/WORLD/asiapcf/07/19/indonesia.earthquake/index.html, accessed on January 17, 2018.

4 "Data terkini Jumlah Penduduk Indonesia Lebih dari 262 Juta Jiwa," http://jateng. tribunnews.com/2017/08/02/data-terkini-jumlah-penduduk-indonesia-lebih-dari-262-juta-jiwa, accessed January 10, 2018. 
ted on the islands of Java and Madura. Approximately $87 \%$ of the population are Muslims. About 9\% are Christians (6.42\% Protestants and 2.58\% Roman Catholics) and approximately $2 \%$ are Hindus, $1 \%$ are Buddhists, and $1 \%$ are traditional beliefs. ${ }^{5}$

Indonesia comprises 35 provinces. There are more than 300 languages and dialects used by the 360 ethnic groups scattered through the islands. ${ }^{6}$ The national and official language is Bahasa Indonesia, which is used nationwide. English is considered the second language and used in big cities.

Indonesia thrives on its cultural diversity, which is systematically preserved through a policy of multiculturalism. This commitment to multiculturalism is expressed in Indonesia's national motto Bhineka Tunggal Ika - Unity in Diversity.

The state ideology is known as Pancasila. It includes five inseparable and mutually qualifying fundamental principles: (1) belief in one supreme God, (2) a just and civilized humanity, (3) the unity of Indonesia, (4) democracy through deliberation and consensus among representatives, and (5) social justice for all people of Indonesia. Pancasila, thus, is the foundation for the social life.

The Gross Domestic Product per capita in Indonesia was last recorded at 3974.10 US dollars in 2016. The GDP per Capita in Indonesia is equivalent to 31 percent of the world's average. ${ }^{7}$ According to World Bank, which updated its global gross domestic product (GDP) data for 2016, the position of Indonesia remains unchanged compared to 2015, at number eight as producer of goods and services based on purchasing power parity $(\mathrm{PPP}){ }^{8}$

5 Bernardus Agus Rukiyanto, "Faith Formation in Pluralistic Indonesia," Quest: Studies on Religion \& Culture in Asia 2 (6 June 2017): 29, https://www.theology.cuhk.edu.hk/ quest/index.php/quest/article/view/45.

6 Bernardus Agus Rukiyanto, "A New Way of Being Church: A Study of Inculturation in the Church of Asia and the Church of Indonesia: A Roman Catholic Perspective." STD Dissertation. Weston Jesuit School of Theology, 2007, 110.

7 "Indonesia GDP per capita," https://tradingeconomics.com/indonesia/gdp-per-capita, accessed January 10, 2018.

8 Faisal Basri, "Indonesia tetap di urutan ke-8 PDB dunia," https://faisalbasri. com/2017/07/03/indonesia-tetap-di-urutan-ke-8-pdb-dunia/ accessed January 10, 2018. 
Following Suharto's downfall in 1998 and Indonesia's transition to democracy, more conservative forms of Islam - often influenced by harsher brands of Middle Eastern Islam - have had space to flourish. The new freedoms have allowed the growth of hard-line groups. They are led by people of Arab, particularly Yemeni origin, like Habib Rizq Shihab, leader of the FPI (Islamic Defense Group) and Abu Bakar Baasir of the MMI (Indonesian Council of Jihad Fighters). These groups take a militant view of jihad as holy war against perceived enemies of Islam rather the mainstream view of jihad as meaning 'exerting oneself to the utmost' in Muslim activities, with war as a last resort. The minority groups, like Ahmadis, Protestant, Catholic and Chinese, have become the target of the extremists or the fundamentalists. Successive governments have been criticized for failing to tackle the radicals for fear of being accused of attacking Islam. ${ }^{9}$

An example case is what happened with Ahok, a Christian governor of Jakarta. In 2017 he was found guilty and sentenced two-year jail for blasphemy against Islam for suggesting that some people had abused a Quranic verse to block his re-election bid. ${ }^{10}$ This event has fueled concerns about the erosion of religious freedoms in Indonesia. Faith-based tension has been mounting in recent years, undermining its pluralist reputation.

Social and political conflicts sometimes have religious overtones and have turned into bloody inter-religious violence. ${ }^{11}$ The rising of Islam fundamentalism becomes one of sources of communal conflicts, the greatest challenge in Indonesia which happen in many places - clashes between rival villages, clashes between ethnic groups, and clashes between religious groups (especially between Christians and Muslims), known as SARA (Suku, Agama, Ras, dan Antar-golongan- ethnic groups, religions, race, and classes). After the political and economic crisis in

9 "Why is religious intolerance on the rise in Indonesia?" http://www.arabnews.com/ node/1096836/world, accessed January 10, 2018.

10 “Ahok guilty of blasphemy, sentenced to two years," http: / /www.thejakartapost.com/ news / 2017/05/09/ahok-guilty-of-blasphemy-sentenced-to-two-years.html, accessed January 15, 2018.

${ }^{11}$ B.A. Rukiyanto, "Peran Gereja Katolik Dalam Membangun Bangsa Indonesia Di Era Reformasi,” Diskursus: Jurnal Filsafat dan Teologi STF Driyarkara, vol. 16, no. 2 (2017): 111. See also M. C. Ricklefs, 2001. A History of Modern Indonesia Since c. 1200, 3rd ed. Stanford, Calif.: Stanford University Press, 415-420. 
1998, the incidence of communal conflicts was not only substantially increase in number but also spread across districts of Indonesia. ${ }^{12}$

Along with the rising of Islam fundamentalism, terrorism becomes a fatal threat in Indonesia. Since 2000 there had been bomb attacks in several places: at 11 churches across the country on Christmas Eve (December 25, 2000), in Bali (October 12, 2002), in front of the J.W. Marriott Hotel in Jakarta (August 5, 2003), outside the Australian Embassy in Jakarta (September 9, 2004), in Tentena, Central Sulawesi, (May 28, 2005), in Bali again (October 1, 2005), suicide bombings in the JW Marriott and Ritz-Carlton Hotels in Jakarta (July 17, 2009), a suicide bomb in Full Gospel Bethel Church in Kepunton, Solo, Central Java (September 25, 2011), The attacks had been blamed on Jemaah Islamiyah, a regional al Qaeda-linked terror group. ${ }^{13}$

The rising of Islamic States (IS) in Iraq and Syria since 2013 has wide influence around the world, including Indonesia. Many jihadists from Indonesia - which has long struggled with Islamist militancy - have in recent years travelled to join IS in Syria and the Philippine city of Marawi. ${ }^{14}$ Multiple explosions near the Sarinah shopping mall in Central Jakarta - including one in a Starbucks cafe - which killed eight people, including four civilians, was the first terrorist attack in Indonesia to be claimed by the Islamic State (January 14, 2016).

Indonesia has been on heightened alert following a string of IS-inspired attacks and plots. The Islamic State (IS) has claimed its fighters are engaged in a standoff with the nation's anti-terror squad at the National Police's Mobile Brigade headquarters' (Mako Brimob) detention center in Depok, West Java on May 9, 2018. ${ }^{15}$ The Surabaya bombings on May 13, 2018 also appear to be the culmination of a series of attacks launched against churches. At least 13 people, mostly churchgoers, died

12 Sujarwoto, "Geography and Communal Conflict in Indonesia," Indonesian Journal of Geography, Vol. 49, No.1, June 2017, 89 - 96, https://journal.ugm.ac.id/ijg/article/ view/26889/pdf, accessed January 10, 2018.

13 "List of terrorist incidents in Indonesia," https://en.wikipedia.org/wiki/List_of_terrorist_incidents_in_Indonesia, accessed 20 January 2018.

14 "Indonesian IS-linked militant jailed for 7 years," http://www.thejakartapost.com/ news/2018/02/12/indonesian-is-linked-militant-jailed-for-7-years.html, accessed January 15, 2018.

15 "Mako Brimob riot: Islamic State claims," http://www.thejakartapost.com/ news/2018/05/09/mako-brimob-riot-islamic-state-claims-standoff-with-anti-terror-squad.html, accessed May 15, 2018. 
in a series of blasts. ${ }^{16}$ In 2016, an IS sympathizer threw a Molotov cocktail at a Protestant church in Samarinda, East Kalimantan, killing a toddler and injuring three other children. On February 11, 2018, another IS sympathizer attacked churchgoers at Sunday Mass in Yogyakarta, injuring four people. ${ }^{17}$

Another challenge to Indonesian government is to restore the rule of law. ${ }^{18}$ The police and legal institutions were corrupted during the Soekarno and Suharto years. Almost the entire legal system is in need of rebuilding. However, the barriers in the way of such change are great, including tainted judges and police, and large amounts of money in the hands of corruptors.

The damage of ecology and environment is another challenge for Indonesia. ${ }^{19}$ Natural disasters such as earthquakes, tsunamis, flood and volcanic eruptions may occur at any time. This condition is worsening since people are unable to protect the environment that may initiate human-induced disasters. As a consequence, Indonesia has become a land of tragedy. For example, in 2010, just after the flood tragedy in Wasior, West Papua, an earthquake-triggered tsunami hit Mentawai Islands, West Sumatra. While we were still shocked by those disasters, Mount Merapi in Yogyakarta erupted. Hundreds of people have been killed in these calamities. Natural disasters have become a great challenge for Indonesians. Environmentalists insisted that the fatal flash floods were caused by environmental degradation in the area (The Jakarta Post, October 15, 2010). In December 2014 floods in Aceh province in the northern tip of Sumatra Island had displaced more than 120,966 people.

In terms of Indonesia's economy, natural catastrophes damage property and stop economic activity, which consequently result in significant financial loss for the people. Furthermore, the series of natural disasters

16 “Surabaya Church bombings," http://www.thejakartapost.com/news/2018/05/13/ surabaya-church-bombings-what-we-know-so-far.html, accessed May 15, 2018.

17 “Man attacks churchgoers at St. Lidwina church inYogyakarta," http: / / www. thejakartapost.com/news / 2018/02/11/man-attacks-churchgoers-at-st-lidwina-church-in-yogyakarta.html, accessed March 15, 2018.

18 M. C. Ricklefs, 2001. A History of Modern Indonesia Since c. 1200, 3rd ed. Stanford, Calif.: Stanford University Press, 421.

19 Ignatia Esti Sumarah, "Moral Lingkungan Hidup: Pentingnya merawat Lingkungan,” Semakin Menjadi Manusiawi, Teologi Moral Masa Kini, B.A. Rukiyanto and Ignatia Esti Sumarah, eds. (Yogyakarta: Penerbit Universitas Sanata Dharma, 2014). See also Rukiyanto, "Peran Gereja Katolik,” 111-112. 
create more burden on the national budget to finance post-disaster rehabilitation. On a macro scale, the increase of natural disasters in this country directly multiplies the number of people living in poverty.

Having discussed the historical background of Indonesia and its some contemporary challenges, now I will explain the Catholic Church in Indonesia.

\section{The Catholic Church in Indonesia}

In the beginning of the sixteenth century the Portuguese discovered the route to Asia via South Africa. In 1511 the Portuguese conquered the town of Malacca and by the end of the year their ships reached Maluku, in the eastern part of Indonesia, and expanded their influences to the northern part of Sulawesi. ${ }^{20}$ In 1521 the Spaniards, led by Magellan, arrived in Maluku by way of the Pacific. Missionaries came along together with the expansion of the Portuguese and Spanish merchants.

In 1534 a Portuguese merchant, Gonzalo Veloso, arrived in Mamuya, on Northern Moro coast. While trading, he evangelized the people. ${ }^{21}$ Soon after 6,000 to 7,000 people were baptized. This event is considered as the beginning of the Catholic Church in Indonesia. ${ }^{22}$ After the action of Francis Xavier in Central Maluku (January - June 1546) and North Maluku (June 1546 - May 1547), Maluku received a better organized mission. Other Jesuits had continued Xavier's mission for decades, despite the opposition from Sultans of the area who then killed some missionaries. At the end of the sixteenth century the number of Catholics reached about 30,000 , twenty percent of the whole population. ${ }^{23}$

20 M. P. M. Muskens, Partner in Nation Building (Aachen: Missio Aktuell Verlag, 1979), 38. See also KWI, The Catholic Church in Indonesia (Jakarta: KWI, 1989), 23. Y. Bakker, "Umat Katolik Perintis di Indonesia," In M.P.M. Muskens, ed., Sejarah Gereja Katolik Indonesia [History of the Catholic Church in Indonesia], vol. 1 (Jakarta: Dokumentasi-Penerangan, Kantor Waligereja Indonesia, 1974), 27-33. Adolf Heuken, "Sejarah Gereja Katolik di Indonesia," Ensiklopedi Gereja, vol. V (Jakarta: Yayasan Cipta Loka Caraka, 1995), 170-171. Adolf Heuken, "Be myWitness to the Ends of the Earth!”: The Catholic Church in Indonesia before the 19th Century (Jakarta: Cipta Loka Caraka, 2002), 14-17.

21 F. Hasto Rosariyanto, ed., Bercermin pada Wajah-wajah Keuskupan Gereja Katolik Indonesia [Reflection on Dioceses of the Indonesian Catholic Church] (Yogyakarta: Penerbit Kanisius, 2001), vii.

22 Michael Coomans, "Evangelization and Inculturation: The Catholic Church of Indonesia,” Indian Missiological Review, vol. 11, no. 3 (October 1989): 262-63.

23 Muskens, Partner in Nation Building, 39. 
Most of the missionaries working in Maluku and North Sulawesi during the Portuguese and Spanish occupations belonged to the Jesuits, who had their mission center and superior in Goa (1542), and the Franciscans, who set their mission centers in Goa (1518), Manila (1578), Malacca (1581), and Macao (1582). From these cities a number of friars would venture into the Nusantara mission-field. ${ }^{24}$

During the period of the Dutch VOC (1602 - 1799), Catholicism was banned until 1806 when Louis Napoleon again granted religious rights to Catholics, following a new era of the Netherlands in which the equality and toleration of religions were promoted. ${ }^{25}$ However, during that period, the Catholic Church in East Nusa Tenggara continued to exist. ${ }^{26}$ Flores, Timor and the smaller islands in the region received missionaries more regularly after the founding of the diocese of Malacca in 1558. The bishop entrusted the mission to the Dominicans with permission of the Dutch VOC. Portuguese soldiers and missionaries visited Flores and Timor several times to expand both the Catholic Church and Portugal's power. In 1559 the Sultan of Solor was baptized, followed by many inhabitants of the island. Solor then became the center of the mission of surrounding islands. In 1606 the number of Catholics reached about 50,000. In 1653 the Dutch VOC occupied Kupang on the most western tip of Timor. The rest of Timor remained under Portuguese influence up to 1976, when East Timor became the twenty-seventh province of Indonesia. Because of that, up to now the majority of the population in Flores and Timor are Catholics.

On March 4, 1807 the Dutch government permitted two diocesan priests, one of whom, Fr. Nelissen, was appointed as Apostolic Prefect of Batavia (now Jakarta) with jurisdiction for the whole of the Netherlands East Indies territory. ${ }^{27}$ On September 20, 1842 an Apostolic Vicariate was established. In 1848 Mgr. V.P. Vrancken, the new Apostolic Vicar, began to think about opening a seminary to provide priests for the expansion of the mission, after the Redemptorists failed to respond to his invitation

24 Meersman, Achilles. The Franciscans in the Indonesian Archipelago, 1300-1775 (Louvain: Nauwelaerts, 1967), 22-27.

25 Coomans, "Evangelization and Inculturation," 263-64.

26 Huub J. W. M. Boelaars, Indonesianisasi: Dari Gereja Katolik di Indonesia Menjadi Gereja Katolik Indonesia (Yogyakarta: Penerbit Kanisius, 2005), 64-67; Muskens, Partner in Nation Building, 41-42.

27 Coomans, "Evangelization and Inculturation," 264. See also KWI, The Catholic Church in Indonesia (Jakarta: KWI, 1989), 27-28. 
to come to Nusantara. ${ }^{28}$ In 1858 he asked the Jesuits from Netherlands to send their members, who came one year later, and in 1893 took over the whole mission in Nusantara. In 1860 the first parish was founded in Larantuka, Flores. After 1902 most areas were gradually handed over to other orders and congregations, the Jesuits retaining only the capital city of Batavia and the important region of Central Java. ${ }^{29}$

After the institutional sanction of the Catholic mission in the Netherlands was abolished with a new constitution in 1848, religious orders came to Nusantara and opened schools and missions in many cities: ${ }^{30}$ the Ursuline Sisters (OSU) in 1856, the Jesuits in 1859, St. Aloysius Brothers (from Oudenbosch) in 1862, Franciscan Sisters (from Heijthuizen) in 1869, Sisters of Tilburg in 1885 in Padang, West Sumatra, and JMJ (Jesus Mary Joseph) Sisters in 1898 in Minahasa. The number of the Catholics gradually increased. A new direction in the Catholic Church was initiated by Fr. Francis van Lith, S.J., who began a teacher training school in Muntilan (Central Java) in $1897 .{ }^{31}$ At that time Van Lith had already applied what we call 'inculturation.' For him learning the language and local culture were an indispensable obligation for missionaries, and missionaries should place themselves on the same level with the Javanese as fellow citizens, and not above them. The success of Kyai Sadrach, a Protestant preacher, among the Javanese people convinced van Lith that educating the indigenous people had multiple advantages.

In 1902 the first region to be separated from the Apostolic Vicariate of Jakarta was the region of Maluku and Irian Jaya (West Papua) and was handed over to the Sacred Heart Missionaries (M.S.C.). ${ }^{32}$ Since then, in the first half of the twentieth century new ecclesiastical territories, both apostolic prefectures and apostolic vicariates, were established and handed over to some orders and congregations: Kalimantan (O.F.M. Cap. and M.S.F.), Sumatra (O.F.M. Cap., S.C.J., and S.S.C.C.), Nusa Tenggara (S.V.D.). Sulawesi (C.I.C.M.) and Java (S.J., O. Carm., C.M., M.S.C.,

28 Boelaars, Indonesianisasi, 79.

29 Bauswein, Jean-Jacques. Vischer, Lukas. The Reformed Family Worldwide. Grand Rapids, Mich.: W.B. Eerdmans, 1999, 226.

30 Boelaars, Indonesianisasi, 82, 85.

31 See F. Hasto Rosariyanto, Father Fransiscus Van Lith, S.J. (1863-1926): Turning Point of the Catholic Church's Approach in the Pluralistic Indonesian Society, Dissertation excerpt (Rome: Pontificia Universitas Gregoriana, 1997), 8-9.

32 KWI, The Catholic Church in Indonesia, 28-30. Boelaars, Indonesianisasi, 85-90. 
and O.S.C.). On January 3, 1961 Pope John XXIII established the hierarchy in Indonesia by his Decree Quod Christus Adorandus. ${ }^{33}$ There were six archdioceses, nineteen dioceses, and two apostolic prefectures at that time. Since then, the Indonesian Catholic Church has grown significantly. Now there are thirty-seven dioceses across the country. ${ }^{34}$

Having reviewed the Catholic Church in Indonesia, now I will explain the meaning of inculturation, followed by exploring the theme of inculturation as understood by the Indonesian bishops in their attempts to become a truly local Church of Indonesia, as well as in responding to the contemporary challenges both of the Church and of the society.

\section{The Meaning of Inculturation}

In general inculturation is understood as an "effort which the Church makes to present the message and values of the gospel by embodying them in expressions that are proper to each culture, in such a way that the faith and Christian experience of each local church is embedded, as intimately and deeply as possible, in its own cultural context." ${ }^{35}$

Aylward Shorter defines inculturation in a simpler way as "the creative and dynamic relationship between the Christian message and a culture or cultures." This definition implies "a continuous dialogue between faith and culture," since culture is always a developing process. ${ }^{36}$ It is important to highlight here that there is an interaction and reciprocal integration between faith and culture, as noted by the extraordinary Synod of Bishops in 1985 that defined inculturation as a "process of reciprocal assimilation between Christianity and culture." 37

33 Boelaars, Indonesianisasi, 139-44.

${ }^{34}$ It is important to note that since 1961 the two Apostolic Prefectures in East Timor have never been counted as part of the Indonesian Bishops' Conference. However, their bishops have always been invited to participate in the annual assembly of the Indonesian Bishops' Conference.

35 “A Working Paper on Inculturation," a document prepared by various members of the $32^{\text {nd }}$ General Congregation under Pedro Arrupe's direction, in On Inculturation, compiled by the Society of Jesus of the Indonesian Province (Semarang: Sekretariat Provinsi Indonesia, 1978), 19. Rukiyanto, “A New Way of Being Church,”13-16.

36 Aylward Shorter. Toward a Theology of Inculturation (Maryknoll, N.Y: Orbis Books, 1989), 11.

37 Anscar J. Chupungco, Liturgical Inculturation (Collegeville, Minn: Liturgical Press, 1992), 28-29. 
According to the language used during the Second Plenary Assembly of the Federation of Asian Bishops' Conferences (FABC) in 1978, inculturation is perceived as a bidirectional encounter of mutual dialogue, critique, and enrichment between the Gospel and cultures (FABC II arts. 11, 30-33). ${ }^{38}$ This statement represents a development in understanding, when compared to the Asian bishops' first statement in 1974, where inculturation was perceived as a unidirectional process in which the Gospel purifies and heals, perfects and fulfills human cultures (FABC I, art. 26).

Pope John Paul II reaffirmed the reciprocal integration between the Gospel and cultures in his definition of inculturation in his 1985 encyclical Slavorum Apostoli (The Apostles of the Slavs), "the incarnation of the Gospel in native cultures and also the introduction of these cultures into the life of the Church." 39

Thus inculturation is not merely external adaptation or acculturation, as the bishops in the 1985 extraordinary Synod had understood it to be. Rather, inculturation requires an "intimate transformation of authentic cultural values through their integration into Christianity and the rooting of Christianity in various human cultures." ${ }^{40}$ In further reflection on inculturation, Chupungco adds the dynamic of transculturation in the process of inculturation, whereby "the interacting parties are able to retain their identity or essential features throughout the process of mutual enrichment... The process of interaction and mutual assimilation brings progress to both." ${ }^{41}$

To protect the reciprocal character of inculturation, in 1980 Bishop Joseph Blomjous suggested the use of the term interculturation ${ }^{42}$ instead

${ }^{38}$ Gaudencio Rosales and C.G. Arévalo (eds.), For All the Peoples of Asia: Federation of Asian Bishops' Conferences Documents from 1970 to 1991, vol. 1 (Maryknoll, N.Y., USA: Orbis Books, 1992), 31. See also B.A. Rukiyanto, "Gereja menurut Federasi Konferensi Waligereja-Konferensi Waligereja Asia," in Menjadi Katekis Handal di Zaman Sekarang, ed. Ignatius L. Madya Utama (Yogyakarta: Sanata Dharma University Press, 2018), 72-74.

39 John Paul II, Slavorum Apostoli, http:/ / www.vatican.va/holy_father/john_paul_ii/encyclicals/documents/hf_jp-ii_enc_02061985_slavorum-apostoli_en.html, accessed on February 9, 2018. See also S. Iniobong Udoidem. Pope John Paul II on Inculturation (Lanham, Md.: University Press of America, 1996), 2-3.

40 "The Final Report of the 1985 Extraordinary Synod," http://www.catholicculture. org/docs/doc_view.cfm?recnum=5132, accessed February 10, 2018.

41 Chupungco, Liturgical Inculturation, 29.

${ }^{42}$ Bernardus A. Rukiyanto, "Interculturation as Threefold Dialogue: Learning Experience 
of inculturation. ${ }^{43}$ However, Shorter advances the use of the term inculturation, since inculturation is always "an intercultural activity with intercultural benefits." 44

Amaladoss, in his book Beyond Inculturation: Can the Many be One?, suggests the need to go beyond inculturation, since "the interaction between the gospel and culture is oriented not so much to the embodiment of the gospel in a given culture, but the transformation of that culture." 45 Here Amaladoss explains that cultures are complex. They include structures of religious, social attitudes and human actions that are in need of change and transformation. Thus, for Amaladoss, inculturation is not only an encounter between the gospel and cultures, but also involves dialogue with other religions in an effort to promote the liberation of the poor. This concept of inculturation was developed further by the FABC, ${ }^{46}$ a point which will be discussed to explore inculturation in the Catholic Church in Indonesia.

\section{INCULTURATION IN THE INDONESIAN Bishops' Conference Documents}

The number of Catholics in Indonesia is less than three per cent of the total population. In spite of this small number, the role of Catholics in Indonesian society has been significant since the beginning of the struggle of the Indonesian nation for its independence in 1945. There have been many Catholic national heroes. They are, among others, Adisutjipto, Slamet Riyadi, Yos Soedarso, and Msgr. Soegijopranoto, S.J. There are also composers of patriotic songs, like Wage Rudolf Soepratman (the national anthem is one of his songs), Cornel Simanjuntak, and Sudjasmin. ${ }^{47}$ Catholics have been successful in presenting to Indonesian society important aspects of the Catholic Church's mission in Indonesia,

from the Church in Asia," Ultimate Reality and Meaning, vol. 30, no. 2 (2007). This article explores further the meaning of interculturation.

43 Shorter, Toward A Theology of Inculturation, 13-17.

44 Shorter, Toward A Theology of Inculturation, 17.

45 M. Amaladoss, Beyond Inculturation (Delhi: Jointly published by Indian Society for Promoting Christian Knowledge for Vidyajyoti Education \& Welfare Society, 1998), 16.

46 Rukiyanto, "Interculturation as Threefold Dialogue," 165-166.

47 Dr. J. Riberu, "Umat Katolik dalam masyarakat Pancasila" [Catholics in the Pancasila Society], Spektrum 2-3 (1984): 26. 
especially in education and health and social services. ${ }^{48}$ This success, of course, cannot be separated from the role of the Indonesian Bishops' Conference (IBC) in leading the Catholic Church.

The IBC has published important documents which serve as guidelines to help the faithful involve themselves in society, for example: Pedoman Kerdja Umat Katolik Indonesia (PKUKI - Action Guidelines for Indonesian Catholics, published in 1970), ${ }^{49}$ Keputusan Bersama Para Peserta Pertemuan Nasional Umat Katolik Indonesia_(KB-PNUKI - Decisions of the Participants of the National Assembly of Indonesian Catholics, published in 1984), ${ }^{50}$ Umat Katolik Indonesia dalam Masyarakat Pancasila (UKIMP - Indonesian Catholics in a Pancasila Society, published in 1985), ${ }^{51}$ and Pedoman Gereja Katolik Indonesia (PGKI - Guidelines for Catholics in Indonesia, published in 1995). ${ }^{52}$

PGKI has taken the place of the 1970 Guidelines (PKUKI). It was composed after long reflection that involved all the faithful, and was promulgated at the end of the first General Assembly of the Indonesian

48 "Sambutan Mgr. Josephus Theodorus Suwatan, M.S.C. di hadapan Bapa Suci pada kunjungan Ad Limina 1996" [The Address of Msgr. Josephus Theodorus Suwatan, M.S.C. to the Holy See during the Ad Limina Visit of 1996], Spektrum 1 (1997): 146.

49 This document proposed guidelines for the participation of Catholics in developing society and country and how to handle its problems. See Pedoman Kerdja Umat Katolik Indonesia [Action Guidelines for Indonesian Catholics] (Jakarta: MAWI, 1970), 5-9, 12. Also: "Challenges for the Church in Indonesia: A Summary of the First and Second Part of the Action Guidelines for Catholics," Internews 1, no. 4 (March 1994): 3.

50 This document was the result of the national gathering called Pertemuan Nasional Umat Katolik Indonesia (PNUKI), celebrating the $450^{\text {th }}$ anniversary of the Catholic Church in Indonesia. This Assembly reflected on the role of the Church in serving the country. See Keputusan bersama para peserta Pertemuan Nasional Umat Katolik Indonesia [The Decisions of the Participants of the National Assembly of Indonesian Catholics] (Jakarta: Sekretariat MAWI, 1984), 2. Also: "Surat gembala para Waligereja Indonesia dalam rangka perayaan the 450 tahun Gereja Katolik di Indonesia” [The Pastoral Letter of the Indonesian Bishops in Celebrating the $450^{\text {th }}$ Anniversary of the Indonesian Catholic Church], Spektrum 1 (1984): 140-41.

51 This document was the result of the reflection and discussion of the IBC for several years regarding the relationship between the Indonesian Catholic Church and the State. See Umat Katolik Indonesia dalam Masyarakat Pancasila [Indonesian Catholics in the Pancasila Society] (Jakarta: Dokpen MAWI, 1985), v-vi.

52 This document was promulgated at the end of the General Assembly of the Indonesian Catholic Church (SAGKI) in celebrating the Golden Jubilee of the proclamation of Indonesia's Independence in 1995. 
Catholic Church (Sidang Agung Gereja Katolik Indonesia - SAGKI I). ${ }^{53}$ Therefore, this document has really become guidelines of and for the faithful in Indonesia. These guidelines give an orientation to the faithful on how to involve themselves in social life and building communion, among themselves and with those embracing different faiths. This document expresses a new commitment of the Indonesian Catholic Church to participate in developing a Pancasila society.

Another important document that is regarded as the historical turning point of the Indonesian Catholic Church is a pastoral letter on political matters called Keprihatinan dan Harapan (KH - Concern and Hope), which was issued in the Lenten Season of 1997. For the first time the bishops spoke out critically against the government and those who were misusing power only for their own interests. The bishops reflected on the national situation and produced directives for Catholics on how to act. ${ }^{54}$ In 2000 the second General Assembly of the Indonesian Catholic Church (SAGKI II) was held, attended by lay, religious, and priests together with their bishops as representatives from all archdioceses and dioceses, with the theme "Empowerment Basic Communities toward a New Indonesia." ${ }^{55}$ In Easter 2001 the IBC issued another pastoral letter to call attention of the faithful about the present situation that the nation was still in "immense and deep trouble." It was an urgent call to act together as a nation to find ways to overcome the situation according to God's will. ${ }^{56}$

In three consecutive years (2003-2006) the IBC has issued three nota pastoral (pastoral notes) which attempted to offer a continuous way to rebuild the nation: socio-political approach (2003) and socio-cultural approach (2004), and socio-economical approach (2006). In 2005 SAGKI III was held to discuss how to make the church be more involved in the society to overcome national crisis. The ongoing conflict in Poso,

53 Pedoman Gereja Katolik Indonesia [Guidelines for the Indonesia Catholic Church] (Jakarta: KWI, 1996), 1.

54 Keprihatinan dan harapan [Concern and Hope] (Jakarta: KWI, 1997), 1-5. The reproduction by the Campus Ministry of Sanata Dharma University is used here.

55 Gereja yang Mendengarkan: Memberdayakan Komunitas Basis menuju Indonesia Baru (Jakarta: KWI, 2003), 11.

56 KWI, Tekun dan Bertahan dalam Pengharapan: Menata Moralitas Bangsa [Perseverance in Hope: Restore the Morality of the Nation] (Jakarta: KWI, 2001), 3-4. 
Central Sulawesi, ${ }^{57}$ and the second Bali bomb, which happened several weeks before the assembly, heightened its concerns.

Indonesian Catholics, as an integral part of the Indonesian nation, continuously make efforts to participate more actively in its development, especially in the country's social-cultural development. The documents of the IBC have functioned as guidelines showing how Catholics as citizens of Indonesia can participate in developing the nation.

Having provided general observation on the IBC documents, in the next section I will explore more specifically the activities of the IBC and its several important documents, which highlight the attempt of the Indonesian church to promote inculturation to become more rooted in Indonesian society.

\section{Toward an Indonesian Catholic Church}

In 1966 and 1968 the assembly of the IBC discussed the follow up of the results of the Vatican II, such as celebrating liturgy in the Indonesian language and empowering the laity in their role both in the church and in society. ${ }^{58}$ In the spirit of ecumenism the IBC approved the use of the Protestant translation of the Bible done by Lembaga Alkitab Indonesia (LAI - Indonesian Bible Institution) and the future cooperation with LAI would be done by Lembaga Biblika Indonesia (LBI - Indonesian Biblical Institution). ${ }^{59}$

The years of 1970-1985 can be seen as a constitutive period for the development of the Catholic Church in Indonesia. ${ }^{60}$ The consciousness to build an indigenous church brought the bishops to issue the first document on Indonesianisasi in the 1970 assembly, which was revised in

57 Between 2000 and 2001 over 1,000 people were killed in a bloody sectarian conflict between Muslims and Christians in Poso. See "Poso beheadings perpetrators 'caught by Army," in http: / /www.thejakartapost.com/yesterdaydetail.asp?fileid=20051109. A07, accessed on April 25, 2018.

58 J. Hadiwikarta, Himpunan Keputusan MAWI 1924-1980 (Jakarta: Penerbit Obor, 1981), 16-17, 23-25, 45, 73.

59 This institution was founded in 1965 by the Franciscans (OFM) with the name "Lembaga Biblika Saudara-saudara Hina" (Franciscan Biblical Institution). In 1970 the IBC took it over and changed its name into "Lembaga Biblika Indonesia" (Indonesian Biblical Institution). LBI, Panorama Kerasulan Kitab Suci di Indonesia (Malang: Penerbit Dioma, 1996), $1-2$.

60 Boelaars, Indonesianisasi, 161. 
1972. 'Indonesianisasi' means integrating and building local church in Indonesia so that the church really rooted and grew in Indonesian society with an Indonesian face. This face has come into focus through a process of integration between Indonesian cultures and the Catholic faith. ${ }^{61}$ The process of Indonesianisasi consists of six concerns: (1) educating priests and religious to have responsibility for the formation of the faithful, to work efficiently, and to have the understanding of indigenous values; (2) that on the parish level, the laity have more responsibility; (3) accelerating the process of Indonesianisasi in religious leadership (foreign superiors need to be replaced by Indonesian people) and lifestyle; (4) Indonesianisasi in education, catechesis, liturgy, and the institutions of the IBC, so that any policy and its application can be made by the Indonesian people; (5) to have more Indonesian bishops; (6) to look for bishop candidates from outside the diocese. The document affirms that this process, however, has happened since the Indonesian people received the Gospel for the first time, not only when the document was announced. ${ }^{62}$

In 1970 the IBC published PKUKI (Action Guidelines for Indonesian Catholics). This document is comprehensive, giving direction to the faithful to participate in developing Indonesian society in all aspects of life: family life, socio-education, socio-politic, and socio-economy. Besides this, the document also speaks about interreligious dialogue and ecumenical cooperation. The document invites all the faithful, bishops, priests, religious, and the laity to cooperate and perform optimally their role in society and in the church. The main point emphasizes how everyone is responsible in building the society. This document is very foundational and has become a reference point for other documents. In this document, the church is understood not as a hierarchical one, but as umat Allah (the people of God), a communion of the faithful, where each member is responsible for the whole community. ${ }^{63}$

As a consequence of the new vision of the church as people of God, the laity has assumed an important role in the church. In many dioceses outside Java they lead Sunday liturgical celebration due to the lack of priests. The directions for the lay leaders were discussed in the 1975

61 KWI, "Indonesianisasi," Spektrum (Jakarta), 1 (1973): 7-11. Also: Hadiwikarta, Himpunan Keputusan, 23-24.

62 KWI, "Indonesianisasi," 7.

63 Boelaars, Indonesianisasi, 154. 
Assembly to help them to optimize their role in basic communities. In the following year the Assembly continued the discussion, focusing on catechesis as faith sharing among the faithful and pastoral services done by the laity. ${ }^{64}$

Regarding the role of the church in politics, in 1971 the Presidium of the IBC issued a declaration on the general election, putting stress on the right to choose freely. In the pastoral letter of 1971, the bishops spoke out on their concerns regarding social unrest, social injustice, corruption, the gap between the rich and the poor, and the oppression of the weak. ${ }^{65}$

The relation between the church and the world, and the church and the government was reflected in the 1974 pastoral letter entitled Partisipasi Gereja dalam Repelita II (the participation of the church in a second five-year economic development plan). ${ }^{66}$ The bishops also evaluated the activities of development both in the government and in the church, based on social welfare and social justice. ${ }^{67}$ Because of its importance, this theme was reprised in the 1978 and 1979 Assemblies to evaluate the participation of the church in the last decade in the process of national development and to discern further the vocation of the church in Indonesian society. ${ }^{68}$ A Jesuit theologian, Robert Hardawiryana, ${ }^{69}$ wrote a document for the assembly, reflecting on four dimensions of national development: cultural, socio-economic, state affairs, and religions.

The relation between the church and the state was specifically discussed in the four consecutive annual assemblies from 1981 - 1984, involving the laity and the discussion in each diocese, to enlighten the laity in their vital role in the development of the country and of the church. ${ }^{70}$ In 1984 a synthesis of the discussion called Keputusan Bersama Para

64 Boelaars, Indonesianisasi, 156-57.

65 Boelaars, Indonesianisasi, 155.

66 A five-year economic development plan was the program of the New Order under President Suharto from 1969. Until the end of Suharto's rule in 1998 Indonesia had experienced six Repelitas. See “Glosary - Indonesia," accessed on July 20, 2006, http: / / lcweb2.loc.gov/frd/cs/indonesia/id_glos.html.

67 Boelaars, Indonesianisasi, 156.

68 Boelaars, Indonesianisasi, 157-58, 175-86.

69 Robert Hardawiryana was one of the leading Indonesian theologians, who had worked a lot for the IBC and the FABC.

70 Boelaars, Indonesianisasi, 159-61. 
Peserta Pertemuan Nasional Umat Katolik Indonesia (KB-PNUKI - Decisions of the Participants of the National Assembly of Indonesian Catholics $)^{71}$ was launched to celebrate 450 years of the presence of the Catholic Church in Indonesia. A year later the bishops published a complete document, summarizing all of results of the former 15 years assemblies since 1970, called Umat Katolik Indonesia dalam Masyarakat Pancasila (UKIMP - Indonesian Catholics in a Pancasila Society). This document can be viewed as a dedicated application of the results of the Vatican II in the Indonesian context.

From 1985 to 1990 the IBC focused their discussions on internal matters of the church, such as theological renewal of Vatican II (1985), the role of Catholic intellectuals in society from a biblical perspective (1986), moral Christianity and ethical guidelines for Catholic hospitals (1987), the renewal of the statutes of the IBC, preparation for the ad limina visit, and permission to extend missionaries' stay (1988), the evaluation of the ad limina visit (May 1989) and of John Paul II's visit to Indonesia (October 9-14, 1989), and the evaluation of the plenary assembly of the FABC V held on July 17-27, 1989 in Bandung, Indonesia (1990).

In 1991 the Bishops invited representatives of the faithful (lay, religious and priests) to reflect on the implication of the social teachings of the Church. As a result, the Church wanted to renew its involvement in social life. The Bishops discussed the matter in their annual meetings from 1993 to 1995. In 1995 at the end of the Great Assembly of the IBC and the faithful (SAGKI I) in celebrating the Golden Jubilee of the proclamation of Indonesia's Independence new guidelines for the Indonesian Catholic church, called Pedoman Gereja Katolik Indonesia (PGKI - Guidelines of the Indonesian Catholic Church) was promulgated as a result of a long reflection and discussion, which involved all the faithful.

The direction of the church of Indonesia is to build a local church, which is responsive to the situation of the society, while being open to the global culture and to the universal church. ${ }^{72}$ Its goal is to build a communion (Kolvovia) to serve the society at large $(\delta 1 \alpha \kappa o v i \alpha) .{ }^{73}$ This

${ }^{71}$ The document explains how the faithful can be intensively involved in the process of the development of Pancasila society in Indonesia. Boelaars, Indonesianisasi, 161.

72 KWI, Pedoman Gereja Katolik Indonesia [Guidelines of the Indonesian Catholic Church] (Jakarta: KWI, 1995), 9-10, 16-17.

73 KWI, Pedoman Gereja Katolik Indonesia, 6-8. 
goal is realized in building a synodal-collegial community with participative mechanism, including women, in its decision-making process. As a symbol and means of the presence of God's love, the church in Indonesia chooses a way of life and service in solidarity with ordinary people, in cooperation and dialogue with people of other religions and beliefs, and in advancing inculturation in liturgy. Besides these, the Indonesian church believes that to be a local church means to be able to fulfill its own need in lay leaders, religious and priests, as well as theologians and thinkers who foster the leadership in the church.

The assembly perceives the Indonesian church as part of and in union with the whole Indonesian people. The church feels all the joys and hopes of the Indonesian people. Therefore the church is called to serve the nation: building a clean and respectful government, fostering its legislative council, and encouraging judicative institutions. In building the nation the Indonesian church acknowledges Pancasila as the foundation of the nation, which unites the whole nation as expressed in the Indonesian motto Bhinneka Tunggal Ika (unity in diversity). ${ }^{74}$ The Church in Indonesia, thus, has developed a "theology of harmony," based on the concept of harmony found in the Indonesian motto Bhinneka Tunggal Ika and the state ideology Pancasila. This concept of harmony has been integrated into teachings and theologies. ${ }^{75}$

In accomplishing its mission together with the whole Indonesian society to construct both qualified human beings by forming good conscience and community in all aspects of life of the church and society at large, the Indonesian church entrusts itself to the power of the Holy Spirit and the grace of God who has redeemed the world in Jesus Christ. ${ }^{76}$

\section{Basic Church Communities}

In the year 2000 the IBC held a general assembly together with the representatives of the faithful (SAGKI II) to discuss and to develop basic church communities. By developing basic communities, the faithful

74 KWI, Pedoman Gereja Katolik Indonesia, 3, 8-9.

75 B. Agus Rukiyanto, "Towards A Theology of Forgiveness: An Indonesian Catholic Perspective on Responding to Interreligious Conflicts," in Filsafat, Etika dan Kearifan Lokal untuk Kostruksi Moral Kebangsaan, eds. Siti Syamsiyatun and Nihayatul Wafiroh, 7 (2013), 128-129. https://www.globethics.net/documents/4289936/13403252/Focus_7_ online_final.pdf/1cf64f1e-3cda-4367-91df-d65a6d808d8c.

76 KWI, Pedoman Gereja Katolik Indonesia, 6-7, 18. 
could realize the life of the church more actively and be more ready to be involved in society as a response to the call of the Holy Spirit to build a new Indonesia, which would be more just, more human, more given to peace, and more certainty of law. ${ }^{77}$

The assembly understood basic community as "a new way of being church... as a small community, where its members can gather periodically to listen to the word of God, to share daily problem both individually or as a group or socially, and to seek its response in the light of the Gospel."78 This kind of community is open to extend its brother-sisterhood to all people of other faiths, enforcing solidarity, especially to those who are poor and oppressed. As a result, the church will become more rooted, more contextual and relevant, and will be able to perform its role to become a better witness to the world. This kind of Church realizes what Pope Francis calls the Church of the poor. ${ }^{79}$

Based on its reflection of the experience in the dioceses, the assembly made some recommendations to make better basic communities: to promote gender equality and healthy ecology, to be more open to people of other faiths, to have a liturgy which moves the faithful to have option for the poor, to build a prophetic-spiritual church, to be more attentive and responsive to the concrete situation of the nation, to have collegial-participative leadership, which involve the youth, religious, women, and the poor in making any decision, and to move from parish-center to basic community-center. ${ }^{80}$

Having discussed how the Indonesian Church developing inculturation, now I will present in the next section the theological reflection of inculturation in the Indonesian Church.

77 KWI, Gereja yang Mendengarkan: Memberdayakan Komunitas Basis menuju Indonesia Baru [The Listening Church: Empowerment Basic Community towards A New Indonesia] (Jakarta: KWI, 2003), 11-12.

78 Two theologians, John Mansford Prior and J.B. Banawiratma, were invited to clarify the meaning of basic community. Gereja yang Mendengarkan, 14-15.

79 B.A. Rukiyanto, "Gereja menurut Paus Fransiskus," in Menjadi Katekis Handal di Zaman Sekarang, ed. Ignatius L. Madya Utama (Yogyakarta: Sanata Dharma University Press, 2018), 87-90.

${ }^{80}$ KWI, Gereja yang Mendengarkan, 17-18. 


\section{Theological Reflection of Inculturation}

In this section I will present the view of inculturation of Robert Hardawiryana, S.J., a Catholic theologian who developed theology of inculturation in Indonesia. Robert Hardawiryana (1926 - 2009) was one of the leading Indonesian theologians. He wrote many books on theology and worked in both the IBC and the FABC.

For inculturation, Hardawiryana uses the term pemribumian, although the term inkulturasi (direct translation from the term inculturation) is commonly used. ${ }^{81}$ For him, inculturation keeps the authentic values of the faith, and at the same time underlines the value of local culture as an expression of the authentic faith.

The subject of inculturation is not the church as an institution, but all the faithful, both collectively and individually, in interaction with the society at large, including interaction with other religious traditions. ${ }^{82}$ Inculturation is not an end in itself, but it is a way towards fulfillment of the faith in Jesus Christ, by the grace of the Holy Spirit, and in the hands of God the Father. Therefore developing a spirituality of the laity is very important here, as well as its pastoral approach. Thus, inculturation deals more with orthopraxis rather than with orthodoxy. Moreover, inculturation is not only constituted by its external expressions, like architecture, rites, organization activities, or institution, but first of all it constitutes an internal mechanism which happens in the person, in his or her deeds, thought, will, attitude, and internal behavior. The faithful are invited to unite and conform to Jesus Christ, following the pattern of incarnation, paschal mystery, and Pentecostal mystery. They are encouraged to learn many kinds of prayer (meditation and contemplation) to internalize Christian values in order to externalize them in concrete life. The realization of Christian values can be achieved by imitating the life of Jesus Christ and by building an authentic brother-sisterhood with people of other religious traditions to foster communion in faith and to build solidarity with the poor and the weak in promoting an integral and healthy ecology.

81 The term pemribumian has a strong value. It means "deeply rooted and penetrated in the inner heart, not only superficial." See Robert Hardawiryana, Umat Kristiani Mempribumi Menghayati Iman Kristiani di Nusantara [Christians Inculturate the Faith in Indonesia] (Yogyakarta: Penerbit Kanisius, 2001), 33-34.

82 Hardawiryana, Umat Kristiani, 28-29, 109, 143-53. 
Facing contemporary challenges, the faithful need to develop and experience a communio of faith in correlation with an Eastern cosmic vision of harmony, which is realized in living together in peace with all people. ${ }^{83}$ On the other hand, amidst the flow of modernization and globalization, the faithful are invited to build up the communio of faith in diaspora, like the first community of the apostles. Basic community, then, is seen as an ideal way to concretize the communio of faith, which extends its communion to the whole society. ${ }^{84}$ Inculturation, therefore, is expected to be transformative, both ad intra and ad extra of the community.

For Hardawiryana inculturation contains three dimensions: (1) relations between the good news of Jesus Christ and cultures ${ }^{85}$ (GS, art. 58); (2) the good news penetrates the whole society, including people of other religious traditions, in a dialogue of life (inter-religious dialogue); (3) preferential option for and with the poor as measurement for an authentic inculturation. ${ }^{86}$

All three dimensions are experienced in two aspects of the church, as expressed in Guidelines of the Indonesian Catholic Church (PGKI),

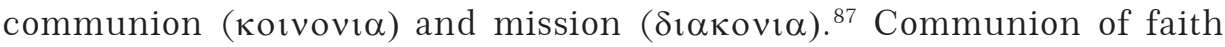
is realized in basic church communities, which expand to basic human communities to build "an authentic brother-sisterhood" ${ }^{88}$

83 Hardawiryana, Umat Kristiani, 143-53.

84 Hardawiryana, Umat Kristiani, 34.

85 Cultures refer to the concrete present situation: plurality of socio-cultures and actual situation in Indonesia, and all efforts to develop talents, to reign the universe by knowledge, to engage in social life, both in families and society, and to express and to protect spiritual experiences for the benefit of all human beings. See Hardawiryana, Umat Kristiani, 86, 89 .

${ }^{86}$ Lifting up the poor is a constitutive dimension of evangelization. Feudalism must be overcome. Hardawiryana, Umat Kristiani, 85.

87 Hardawiryana, Umat Kristiani, 84, 86-87.

88 The term "persaudaraan sejati" (authentic brother-sisterhood) is firstly promoted by Julius Cardinal Darmaatmadja, S.J. to respond to the situation of crisis and conflicts to promote an authentic brother-sisterhood among all Indonesian people to overcome together the crisis and the conflict. Later the term becomes commonly used in many documents of the church. 
To be effective and integrative, inculturation is promoted not only in parishes (pastoral territorial), but also in pastoral movements, like groups according to age or profession. ${ }^{89}$

Hardawiryana offers some ideas from the perspective of philosophy and phenomenology as the foundation for inculturation of faith. He distinguishes two visions as developed in western and eastern cultures: an anthropocentric vision (western approach) and a cosmic vision (eastern approach)..$^{90}$ The anthropocentric vision has been developed since humanism, renaissance, and the Enlightenment, and paradoxically has destroyed the image of human being, as well as ecology, when this vision transmitted into egocentrism and individualism. A full autonomy of human being to achieve the progress of technology without considering its negative effects has become a threat for the continuity of human being and ecology.

The cosmic vision, on the other hand, perceives reality as communion, harmony, and balance. The human being is part of this communion, which forms reality as organic wholeness. There is an intrinsic relation between ecology and prosperity. The basic attitude of the human beings is static-integrative, that is an attempt to conserve their place in cosmic in harmony with other elements of the universe. It is different from the architectonic approach in which basic attitude is active-dynamic, where justice is realized in distributing goods to every one according to one's needs. In the architectonic approach, the main value is justice, while in the cosmic vision, the main value is harmony. However, a cosmic vision is basically not in contradiction with architectonic vision. Both are complementary and corrective of one another.

\section{REFlection: A Journey TOWARDS the Indonesian Catholic Church}

For Catholics the role of the IBC is very important in leading the faithful in a journey towards an Indonesian church, a church rooted in local cultures and in society. After Vatican II the IBC was encouraged to implement inculturation as a new way of being church. The period of 1970-1985 can be seen as a constitutive period for the development of

89 The idea of pastoral movement is developed by Mangunwijaya, a diocesan priest who dedicated all his life for the poor and by publishing many writings. SeeY.B. Mangunwijaya, Gereja Diaspora [Diaspora Church] (Yogyakarta: Penerbit Kanisius).

90 Hardawiryana, Umat Kristiani, 91-94. 
the Indonesian Catholic Church until the promulgation of Umat Katolik Indonesia dalam Masyarakat Pancasila (UKIMP - Indonesian Catholics in a Pancasila Society), a document which can be seen as a kind of application of the results of the Vatican II in Indonesian context.

Together with the development of the country, the bishops and the faithful continue their journey to become more rooted in Indonesian soil until the promulgation of Pedoman Gereja Katolik Indonesia (PGKI Guidelines for Catholics in Indonesia) in 1995, a document which gave an orientation to the faithful on how to involve themselves in social life and building communion, among themselves and with those embracing different faiths, and expresses a new commitment of the Indonesian Catholic Church to participate in developing a Pancasila society

When needed, the bishops included in their messages their understanding of God and of the Church as the foundation of their responses. Thus, they are assured that their statements would not be taken as expressing merely social concern. What the faithful do must be based on Christian faith. The bishops have taught the faithful to act in the light of the Gospel.

The documents of the IBC show that the bishops have reflected on the overall situation and responded to concrete cases. They have been able to read the "signs of the times" and have interpreted them in the light of the Gospel (GS 4) and then have responded to them operatively through discernment. Therefore they have realized their Christian faith in dealing with cultural, religious, social, economic, and political realities. ${ }^{91}$ Through this methodology of reading the "signs of the times," the bishops have concretized the role of the Church as servant and prophet for society. ${ }^{92}$ Moreover, they have integrated Pancasila, which comprises universal moral principles, into the Church's social teaching and thus they have developed an indigenous social teaching of the Church.

Facing contemporary challenges, the Church works together with the entire nation. The involvement of the Church leaders in society has

91 B.A. Rukiyanto, "Katekese di Tengah Arus Globalisasi," in Pewartaan di Zaman Global, edited by B. A. Rukiyanto (Yogyakarta: Penerbit Kanisius, 2012), 63-64.

92 See Robert Hardawiryana, S.J., “Bedah buku: 'Ajaran sosial Gereja' 1891-1991” [A Study of the Social Teaching of the Church - 1891-1991], Spektrum 2 (2000): 103. The IBC rarely cites the social teaching of the Church in its documents. PGKI cited Sollicitudo Rei Socialis only once, on page 32, and the UKIMP Octogesima Adveniens only on page 13. 
made the Church more credible to people of other faiths. People of other faiths appear more convinced of the role of the Catholic Church in building society. The Church has thus become more rooted in the Indonesian nation and has become more truly the Indonesian Catholic Church.

Being aware of the challenge of poverty, it is clear to the bishops that the Church must have a preferential option for the poor. Through their statements and messages the bishops have affirmed this option and made it central to the indigenous social teaching of the Church. They have expressed their solidarity with the poor and invited the faithful to help them, together with people of other faiths.

The bishops have noted that the unity of the nation is in danger. There have been many conflicts due to differences in religions, ethnic groups, tribes, and interests (SARA - Suku, Agama, Ras, dan Antar-golongan ethnic groups, religions, race, and classes). In this situation, the bishops have been aware of the role of the Church in bringing reconciliation and peace to society. In their messages the bishops have promoted efforts to build an authentic brother-sisterhood. The differences in society should not become the source of conflict, but rather the means for building the nation and fostering national unity based on Pancasila and Bhinneka Tunggal Ika. The bishops have encouraged the faithful to make the dialogue of life a reality in society. In doing this the bishops have facilitated national reconciliation.

The IBC has invited all people to renew their commitment to build the nation. It is time to reconcile with one another. It is time to forget all past hatreds caused by irresponsible people, and to be ready to help one another, to work together, and to build an authentic brother-sisterhood. In response to this invitation, the faithful make many efforts to involve in interreligious dialogue, to help the poor and the victims with their involvement in NGOs, including those run by the religious or the laity, which has multi ethnic and multi faith characteristics.

The members of the church have become more aware of its call to be more united with society, to be more in solidarity with the people and their problems. ${ }^{93}$ They have become more aware of its calling to respond to all the challenges in society with its Christian faith. It is the mission of the Church to promote justice as the realization of faith.

93 “Sambutan Ad Limina 1996," 146. 
All kinds of challenges have made the Indonesian Catholic Church - the bishops with their documents and statements; the priest, the religious, and the laity with their involvement in their activities in serving the poor together with people of other faiths, in interreligious dialogue - more united with the people, feeling their joy and hope, their sorrow and concern. All the members of the Church have attempted to respond to the 'signs of the times.' The Church in Indonesia has become "the Church of Indonesia," ${ }^{94}$ inculturated in local cultures and concrete situations of society, actively participating in the life and struggle of the nation. The desire of the bishops and the faithful in the SAGKI I (1995) ${ }^{95}$ to be "the Church rooted in the faithful and the faithful rooted in society" (Gereja yang mengumat dan umat yang memasyarakat) has become more a reality.

\section{Bibliography}

"A Working Paper on Inculturation." A document prepared by various members of the $32^{\text {nd }}$ General Congregation under Pedro Arrupe's direction. In On Inculturation. Compiled by the Society of Jesus of the Indonesian Province. Semarang: Sekretariat Provinsi Indonesia, 1978.

"Ahok guilty of blasphemy, sentenced to two years." http://www.thejakartapost. com/news/2017/05/09/ahok-guilty-of-blasphemy-sentenced-to-twoyears.html. Accessed January 15, 2018.

Amaladoss, M. Beyond Inculturation. Delhi: Jointly published by Indian Society for Promoting Christian Knowledge for Vidyajyoti Education \& Welfare Society, 1998.

Bakker, Y. "Umat Katolik Perintis di Indonesia." In M.P.M. Muskens, ed., Sejarah Gereja Katolik Indonesia [History of the Catholic Church in Indonesia]. Vol. 1. Jakarta: Dokumentasi-Penerangan, Kantor Waligereja Indonesia, 1974, 27-36.

Bauswein, Jean-Jacques. Vischer, Lukas. The Reformed Family Worldwide. Grand Rapids, Mich.: W.B. Eerdmans, 1999.

Boelaars, Huub J. W. M. Indonesianisasi: Dari Gereja Katolik di Indonesia Menjadi Gereja Katolik Indonesia. Yogyakarta: Kanisius, 2005.

94 During his visit in 1989 John Paul II himself affirmed that the Church in Indonesia has become "the Church of Indonesia." See "Refleksi Sri Paus tentang perlawatannya ke Indonesia" [The Reflections of the Pope on His Visit to Indonesia], Spektrum 1-4 (1990): 97. Emphasis added.

95 “Sambutan Ad Limina 1996," 145-46. 
"Challenges for the Church in Indonesia: A Summary of the First and Second Part of the Action Guidelines for Catholics." Internews 1. No. 4 (March 1994): 3.

Chupungco, Anscar J. Liturgical Inculturation. Collegeville, Minn: Liturgical Press, 1992.

Coomans, Michael. "Evangelization and Inculturation: The Catholic Church of Indonesia," Indian Missiological Review. Vol. 11. No. 3 (October 1989): 262-63.

"Country Profile: Indonesia." http://news.bbc.co.uk/2/hi/asia-pacific/country_ profiles/1260544.stm. Accessed January 17, 2018.

"Data terkini Jumlah Penduduk Indonesia Lebih dari 262 Juta Jiwa," http:// jateng.tribunnews.com/2017/08/02/data-terkini-jumlah-penduduk-indonesia-lebih-dari-262-juta-jiwa. Accessed January 10, 2018.

Esti Sumarah, Ignatia. "Moral Lingkungan Hidup: Pentingnya merawat Lingkungan," Semakin Menjadi Manusiawi, Teologi Moral Masa Kini. B.A. Rukiyanto and Ignatia Esti Sumarah. Eds. Yogyakarta: Penerbit Universitas Sanata Dharma, 2014.

Faisal Basri. "Indonesia tetap di urutan ke-8 PDB dunia." https://faisalbasri. com/2017/07/03/indonesia-tetap-di-urutan-ke-8-pdb-dunia/. Accessed January 10, 2018.

"Glossary - Indonesia." http://lcweb2.loc.gov/frd/cs/indonesia/id_glos.html. Accessed January 10, 2006.

Hadiwikarta, J. Himpunan Keputusan MAWI 1924-1980. Jakarta: Obor, 1981.

Hardawiryana, Robert. "Bedah Buku: Ajaran sosial Gereja' 1891-1991" [A Study of the Social Teaching of the Church - 1891-1991]. Spektrum 2 (2000): 103.

Hardawiryana, Robert. Umat Kristiani Mempribumi Menghayati Iman Kristiani di Nusantara [Christians Inculturate the Faith in Indonesia]. Yogyakarta: Penerbit Kanisius, 2001.

Hasto Rosariyanto, F. (ed.). Bercermin pada Wajah-wajah Keuskupan Gereja Katolik Indonesia [Reflection on Dioceses of the Indonesian Catholic Church]. Yogyakarta: Penerbit Kanisius, 2001.

Hasto Rosariyanto, F. Father Fransiscus Van Lith, S.J. (1863-1926): Turning Point of the Catholic Church's Approach in the Pluralistic Indonesian Society. Dissertation excerpt. Rome: Pontificia Universitas Gregoriana, 1997. 
Heuken, Adolf. "Be my Witness to the Ends of the Earth!": The Catholic Church in Indonesia before the 19th Century. Jakarta: Cipta Loka Caraka, 2002.

Heuken, Adolf. "Sejarah Gereja Katolik di Indonesia." Ensiklopedi Gereja. Vol. V. Jakarta: Yayasan Cipta Loka Caraka, 1995: 165-203.

"Indonesia." http://www.arkeologi.net. Accessed January 10, 2018.

"Indonesia." http://www.indonesia.go.id and http://www.lin.go.id/default.asp. Accessed January 10, 2018.

"Indonesia." http://www.infoplease.com/ipa/A0107634.html. Accessed January 10, 2018.

"Indonesia GDP per capita." https://tradingeconomics.com/indonesia/ gdp-per-capita. Accessed January 10, 2018.

"Indonesian IS-linked militant jailed for 7 years." http://www.thejakartapost. com/news/2018/02/12/indonesian-is-linked-militant-jailed-for-7-years. html. Accessed January 15, 2018.

"Java Death Toll Tops 500." http://edition.cnn.com/2006/WORLD/asiapcf/07/19/ indonesia.earthquake/index.html. Accessed January 17, 2018.

John Paul II. Slavorum Apostoli. http://www.vatican.va/holy_father/john_paul_ ii/encyclicals/documents/hf_jp-ii_enc_02061985_slavorum-apostoli_ en.html. Accessed February 9, 2018.

KWI. Gereja yang Mendengarkan: Memberdayakan Komunitas Basis menuju Indonesia Baru [The Listening Church: Empowerment Basic Community towards A New Indonesia]. Jakarta: KWI, 2003.

KWI. "Indonesianisasi." Spektrum. No. 1 (1973): 7-11.

KWI. Keprihatinan dan harapan [Concern and Hope]. Jakarta: KWI, 1997.

KWI. Pedoman Gereja Katolik Indonesia [Guidelines of the Indonesian Catholic Church]. Jakarta: KWI, 1995

KWI. "Surat gembala para Waligereja Indonesia dalam rangka perayaan the 450 tahun Gereja Katolik di Indonesia" [The Pastoral Letter of the Indonesian Bishops in Celebrating the $450^{\text {th }}$ Anniversary of the Indonesian Catholic Church]. Spektrum 1 (1984): 140-41.

KWI. Tekun dan Bertahan dalam Pengharapan: Menata Moralitas Bangsa [Perseverance in Hope: Restore the Morality of the Nation]. Jakarta: KWI, 2001. 
KWI. The Catholic Church in Indonesia. Jakarta: KWI, 1989. "List of terrorist incidents in Indonesia." https://en.wikipedia.org/wiki/List_of_terrorist_incidents_in_Indonesia. Accessed January 20, 2018.

"Mako Brimob riot: Islamic State claims," http://www.thejakartapost.com/ news/2018/05/09/mako-brimob-riot-islamic-state-claims-standoffwith-anti-terror-squad.html. Accessed May 15, 2018.

"Man attacks churchgoers at St. Lidwina church in Yogyakarta," http://www.thejakartapost.com/news/2018/02/11/man-attacks-churchgoers-at-st-lidwina-church-in-yogyakarta.html. Accessed March 15, 2018.

Mangunwijaya, Y.B. Gereja Diaspora [Diaspora Church]. Yogyakarta: Penerbit Kanisius, 1999.

MAWI. Keputusan bersama para peserta Pertemuan Nasional Umat Katolik Indonesia [The Decisions of the Participants of the National Assembly of Indonesian Catholics]. Jakarta: Sekretariat MAWI, 1984.

MAWI. Pedoman Kerdja Umat Katolik Indonesia [Action Guidelines for Indonesian Catholics]. Jakarta: MAWI, 1970.

MAWI. Umat Katolik Indonesia dalam Masyarakat Pancasila [Indonesian Catholics in the Pancasila Society] (Jakarta: Dokpen MAWI, 1985).

Meersman, Achilles. The Franciscans in the Indonesian Archipelago, 1300-1775. Louvain: Nauwelaerts, 1967.

Muskens, M. P. M. Partner in Nation Building. Aachen: Missio Aktuell Verlag, 1979.

"Poso beheadings perpetrators 'caught by Army." http://www.thejakartapost. com/yesterdaydetail.asp?fileid=20051109.A07. Accessed April 25, 2018.

"Refleksi Sri Paus tentang perlawatannya ke Indonesia" [The Reflections of the Pope on His Visit to Indonesia], Spektrum 1-4 (1990): 97.

Riberu, J. "Umat Katolik dalam masyarakat Pancasila" [Catholics in the Pancasila Society]. Spektrum 2-3 (1984): 26.

Ricklefs, M. C. A History of Modern Indonesia Since c. 1200, 3rd ed. Stanford, Calif: Stanford University Press, 2001.

Rosales, Gaudencio and C.G. Arévalo (eds.). For All the Peoples of Asia: Federation of Asian Bishops' Conferences Documents from 1970 to 1991. Vol. 1. Maryknoll, N.Y., USA: Orbis Books, 1992. 
Rukiyanto, Bernardus Agus. "A New Way of Being Church: A Study of Inculturation in the Church of Asia and the Church of Indonesia: A Roman Catholic Perspective.” STD Dissertation. Cambridge, Mass.: Weston Jesuit School of Theology, 2007.

Rukiyanto, Bernardus. "Faith Formation in Pluralistic Indonesia." Quest: Studies on Religion \& Culture in Asia 2 (6 June 2017): 25-41. https://www. theology.cuhk.edu.hk/quest/index.php/quest/article/view/45.

Rukiyanto, B.A. "Gereja menurut Federasi Konferensi Waligereja-Konferensi Waligereja Asia." In Menjadi Katekis Handal di Zaman Sekarang, edited by Ignatius L. Madya Utama, 67-84. Yogyakarta: Sanata Dharma University Press, 2018.

Rukiyanto, B.A. "Gereja menurut Paus Fransiskus." In Menjadi Katekis Handal di Zaman Sekarang, edited by Ignatius L. Madya Utama, 85-111. Yogyakarta: Sanata Dharma University Press, 2018.

Rukiyanto, Bernardus A. "Interculturation as Threefold Dialogue: Learning Experience from the Church in Asia." Ultimate Reality and Meaning 30, no. 2 (2007): 165-173.

Rukiyanto, B.A. "Katekese di Tengah Arus Globalisasi." In Pewartaan di Zaman Global, edited by B.A. Rukiyanto, 57-90. Yogyakarta: Penerbit Kanisius, 2012.

Rukiyanto, B.A. "Peran Gereja Katolik Dalam Membangun Bangsa Indonesia Di Era Reformasi." Diskursus: Jurnal Filsafat dan Teologi STF Driyarkara 16, no. 2 (2017): 105-137.

Rukiyanto, B. Agus, "Towards a Theology of Forgiveness: An Indonesian Catholic Perspective on Responding to Interreligious Conflicts." in Filsafat, Etika dan Kearifan Lokal untuk Kostruksi Moral Kebangsaan. Edited by Siti Syamsiyatun and Nihayatul Wafiroh. Focus 7 (2013), 127-145. https://www.globethics.net/documents/4289936/13403252/Focus_7_ online_final.pdf/1cf64f1e-3cda-4367-91df-d65a6d808d8c.

Shorter, Aylward. Toward a Theology of Inculturation. Maryknoll, N.Y: Orbis Books, 1989.

Sujarwoto. "Geography and Communal Conflict in Indonesia." Indonesian Journal of Geography. Vol. 49. No.1 (June 2017): 89 - 96. https://journal. ugm.ac.id/ijg/article/view/26889/pdf. Accessed January 10, 2018.

"Surabaya Church bombings." http://www.thejakartapost.com/news/2018/05/13/ surabaya-church-bombings-what-we-know-so-far.html. Accessed 15 May 2018. 
"The Final Report of the 1985 Extraordinary Synod." http://www.catholicculture. org/docs/doc_view.cfm?recnum=5132. Accessed February 10, 2018.

Udoidem, S. Iniobong. Pope John Paul II on Inculturation. Lanham, Md.: University Press of America, 1996.

"Why Is Religious Intolerance on the Rise in Indonesia?" http://www.arabnews. com/node/1096836/world. Accessed January 10, 2018. 
